\title{
From Global Unions to the Shop Floor: Trade Union Networks in Transnational Corporations in Brazil
}

\author{
Ricardo Framil Filho and Leonardo Mello e Silva \\ University of São Paulo, Brazil
}

\begin{abstract}
This article analyses the origins, development and organisation of cross-union, company-based trade union networks in transnational corporations in the metal and chemical industries in Brazil. Collectively developed by local, national, foreign and international trade union organisations, this kind of union action was introduced in the country in the early 2000s as a way to connect local labour representatives organising workers in different locations within the same company. Networks strengthen local labour power and stimulate transnational connections. Promoting solidarity among workers across multiple factories, they offer the perspective for a global unionism connected to shop-floor organisation. Despite these achievements, networks face important challenges. Power imbalances, the reliance on restrictive social dialogue arrangements and the compromise with traditional structures limit the reach of the strategy.
\end{abstract}

\section{KEY WORDS}

globalisation; trade unions; new labour transnationalism; trade union networks; Brazil

\section{Introduction}

Against the backdrop of globalisation, there has been renewed interest in labour internationalism among scholars and workers' organisations alike. Within the traditional international union structures, the adoption of a broader agenda suggested the possibility of new alliances (O'Brien, 2000). At the same time, innovative forms of transnational organisation were conceived to take advantage of political opportunities and communications technologies in order to supersede a customary "diplomat model of trade union internationalism" (Hyman, 2005). In this regard, new union strategies in transnational corporations (TNCs) have been particularly significant (Bourque and Hennebert, 2011).

As noted by Evans (2010: 352), global corporations "give far-flung workers common targets" and, moreover, their "corporate organisational structures provide road maps for the spread of global campaigns". Along these lines, Wills (1998: 127) notes that the creation of cross-border union alliances in TNCs suggest that "the role of the international trade union movement may be refigured away from vertical representation toward the coordination and management of a network of trade unionists stretching across the global economy". Indeed, transnational networks of union representatives working within the same company in different locations have provided many of the examples associated with the emergence of "a non-hierarchical form of internationalism, organizing locally and connecting place to place globally" (Webster, Lambert and Bezuidenhout, 2008: 208).

Important studies on the subject have focused on efforts led by Global Union Federations 
(GUFs), international bodies dedicated to specific industries or professions. According to McCallum (2013: 5), "nearly all instances of labour transnationalism emerge from within individual GUFs". The most notable outcome has been the signing of numerous Global Framework Agreements (GFAs), documents which, in spite of their unreliable enforceability, imply the recognition of a global mandate attributed to GUFs. Moreover, these agreements have been linked to the creation of new organisational forms aimed at developing a "global unionism" connected to proper industrial campaigns in the workplaces. In that manner, Fairbrother and Hammer (2005: 422) argue that "what is novel is the ways in which framework agreements, the negotiations that lead up to them and associated campaigns are rooted in the day-to-day realities of members and not the musings of remote international leaders".

Emphasising the multiscalar nature of contemporary union strategies, Ford and Gillan (2015: 458) note that GUFs "are distinct from national and local unions in that they have an identifiable mandate to think, act and represent workers on a transnational basis", but acknowledge that "the locus of union resources, authority structures and mobilisation remains local and national". Likewise, Garver et al. (2007: 239) reason that, despite their efforts to establish a proper global mandate, "GUFs, which have affiliated unions rather than direct members, must rely on those affiliates for democratic legitimization and for organising local actions". The consequence is that global union initiatives are in practice carried out cooperatively by organisations with different priorities, powers and prerogatives.

In view of that, recent studies have emphasised the persistence of national concerns and regional imbalances amid the constitution of transnational union alliances. Cotton and GumbrellMcCormick (2012: 716) argue that the prevalence of regional or bi-national contours in many such initiatives may leave "power dynamics between trade unions from the global North and South intact, subordinating international priorities to the interests of the key players". Regarding the manufacturing sector, in particular the motor industry, Anner et al. (2006: 22) contend that "national interests matter a great deal" and that domestic peculiarities motivated the leadership role assumed by German unions and produced relative disinterest in countries such as the United States. Furthermore, strict reliance on European conceptions of social dialogue and partnership has been identified as an obstacle to the efficacy of GFAs and associated strategies in a broader sense (Fichter and McCallum, 2015). Overall, these findings indicate that the challenges and opportunities involved in the diffusion of global union policies constitute an important subject matter.

\section{The Present Research}

Considering the previous remarks, the question of whether and in which ways global strategies can be connected to the regular activities of local unions in different contexts is noteworthy. Moreover, it is important to understand how unions that are under-resourced, separated from TNCs' headquarters and far away from the traditional backbone of international unionism may influence and take advantage of policies initially fostered in foreign settings. In order to explore these questions, in this article we analyse the undertakings of company-based, cross-union networks in the chemical and metal industries in Brazil. Conceived as part of a larger drive to build global union alliances in TNCs and simultaneously to deal with local challenges, these networks have been supported by international, foreign and domestic organisations.

Accordingly, we adopted a framework aimed at establishing the multiscalar entanglements at play. At the international level, we interviewed Brazilian and foreign leaders of IndustriALL Global Union, the largest GUF and responsible for most manufacturing sectors. Additionally, we 
contacted representatives from the International Trade Union Confederation (ITUC) and the Trade Union Confederation of the Americas (TUCA). Foreign national organisations are represented by the Dutch Federatie Nederlandse Vakbeweging (FNV), the German Deutscher Gewerkschaftsbund (DGB) and its associated unions IG Metall and IG BCE, alongside solidarity foundations Friedrich Ebert Stiftung and the Solidarity Center of the American Federation of Labor and Congress of Industrial Organizations (AFL-CIO). Within domestic entities, we studied the role of the Central Única dos Trabalhadores (CUT), Força Sindical (FS) and their national confederations in the metal and chemical industries. Finally, research institutes such as the Social Observatory Institute (IOS) and the Inter-Union Department of Statistics and Socio-Economic Studies (DIEESE) are relevant in providing networks with research and information.

The role of organisations conceiving and supporting networks from above is important, but our main goal is to bring to the forefront the impact of situations which are often less visible those involving local representatives concerned with everyday struggles in the factories. In this manner, the second part of our research focused on local union officials organising in specific companies. Preliminary attempts at mapping networks revealed that their status and composition can change rather quickly. We thus decided that a thorough account of the tensions and prospects manifested in the process of building networks should prevail over a static evaluation of the existing structures at a specific point in time. To that end, we selected a sample of networks in different stages of development, which allowed us to explore examples of success as well as those of networks facing greater difficulties in different settings. Further on, we present an overview of the latest available data on currently active networks, but for the main body of the research we analysed fifteen networks in German (7), American (3), Brazilian (2), Dutch (1), French (1) and Belgian (1) TNCs. On this front, we conducted interviews with local leaders and workplace representatives associated with different metal and chemical unions in the states of São Paulo, Rio de Janeiro, Minas Gerais, Rio Grande do Sul and Pernambuco.

For the most part, the research was carried out from 2014 to 2017. Additional fieldwork conducted in the two subsequent years was used in a complementary manner and to shine light on recent events. During the main stage of the research, forty-one trade unionists were subjected to in-depth, semi-structured interviews. Furthermore, our immersion in the field placed us in contact with many others. We have observed several events arranged to organise and discuss union networks in TNCs, which included union seminars, congresses and meetings at the national and international levels, but also smaller, regular activities of local union representatives engaged in specific networks. Finally, we took advantage of documentary research on the subject. In this regard, bulletins distributed to workers in the factories and internal reports on network activities were particularly useful.

\section{International Union Cooperation in TNCs in Brazil}

Instances of international cooperation in foreign corporations in Brazil are reported as early as the 1970s, when local unions took advantage of connections established within multinationals to mobilise foreign solidarity against human rights violations and anti-labour practices under the military dictatorship. These contacts continued to be developed over the years. Notably, an enduring cooperation between metalworkers associated with the CUT in Greater São Paulo's $\mathrm{ABC}$ manufacturing cluster and their German counterparts in major automakers was important to the development of an internationalist approach to organising in TNCs in the country (Anner, 2003). This "internationalism à la São Bernardo" (Oliveira, 2006) was influential on domestic perceptions of the international union movement, but the dissemination of the strategy was 
limited by the fragmented nature of domestic union representation. Not surprisingly, it was concomitant with campaigns for a national metalworkers' contract, a demand that is yet to be fulfilled.

In Brazil, a single state-recognised autonomous union is responsible for every worker in specific industries inside a delimited territorial basis as narrow as a single municipality. ${ }^{1}$ Additionally, up until very recently local unions were entitled to compulsory contributions informally known as the "union tax". The consequence is the existence of a multitude of small unions led by officials strongly attached to their local powers and prerogatives, not least because they manage a stable source of income that is not dependent on the voluntary association of workers. ${ }^{3}$ All told, unions willing and capable of reaching out to foreign allies were an exception, not the rule.

The limitations of local unionism were increasingly manifest from the late 1990s, when important foreign manufacturers established subsidiaries in greenfield sites in the country (Abreu, Beynon and Ramalho, 2000). At the same time, intensified global competition was disturbing long-established local arrangements. In the words of a workplace representative in a traditional auto parts factory in operation since the 1960s, “Today, 'we' are our biggest competitor. We are up against 'ourselves' in the United States, China or India. Within Brazil, someone takes our production to Minas Gerais. What can you do?” (Interview R1, September 2018). The usual local scope was no longer sufficient. According to a workplace representative in another company, reaching beyond the local meant "a huge change of culture, especially for Brazilian unionists, accustomed to a narrow horizon". He added, however, that it was a "matter of survival" (Interview R2, July 2014).

Demands for the overhaul of legal restrictions on union organisation have been continuously affirmed at the national level, but the decades-old legislation supporting the autonomy of local unions has proved remarkably resilient. Under these circumstances, new ideas on cross-border alliances in TNCs proposed by GUFs around the turn of the century offered an appealing alternative to challenge the isolation of local union representatives, both inside the country and at the transnational level. CUT, which had established an early engagement with the reorganisation of the international union movement, was well positioned to spearhead the introduction of global union strategies in Brazil (Costa, 2009).

The decisive step was the creation of the "Action on Multinationals Project", commonly known as "CUT-Multi", an initiative developed by CUT's International Relations Secretariat in cooperation with Dutch union federation FNV. The project proposed that unions affiliated to CUT should be "part of the forefront of international action along with global unions against the nefarious actions of multinationals" and stressed the need to involve "local unions from the workplace, with direct participation of local representatives" (CUT, 2006: 65). The project introduced new strategies to unionists in different industries, strategies such as GFAs and company networks. Furthermore, a model of organisation aimed at creating national alliances in Brazil was developed, and several initiatives that were eventually meant to be incorporated in global networks organised by GUFs were created.

A few years later, CUT acknowledged the project's "strategic importance" and established

\footnotetext{
${ }^{1}$ A detailed analysis of the influence of corporatist laws on Brazilian trade unions is provided by Lang and Gagnon (2009).

2 The union tax was abolished in 2016. We return to this point in the concluding remarks.

${ }^{3}$ Campos (2016) found 10817 unions in Brazil, and showed that 80.4 per cent of those covered only one or a few municipalities.
} 
company networks as "instruments of workplace organisation for the central as a whole" (CUT, 2006: 65). Moreover, networks have been able to expand their influence beyond CUT, reaching unions linked to different political tendencies. This was facilitated by the mitigation of domestic union rivalries after the Workers' Party took office in 2003 and by the fact that IndustriALL has attracted new Brazilian affiliates, lending its global legitimacy to the strategy. Nevertheless, much of the appeal of company union networks resulted from their own achievements. As an FS leader acknowledged, CUT's successes in this arena made them realise they were being "left behind" (Interview R3, August 2014). Today, networks are well-known among unions in the country, notably in the metal and chemical industries. ${ }^{4}$

\section{Building Union Networks}

Given the concentration of union powers at the local level in Brazil, the participation of local union officials and workplace representatives is vital to the success of company networks. A CUT-Multi specialist argued that "local unions are decisive, irreplaceable. If they say they won't join, the network doesn't happen" (Interview R4, August 2014). On the other hand, local unions do not build networks on their own. In the words of a workplace representative at a German automobile manufacturer, "You're consumed by daily issues, by the problems in each factory. You get so involved you don't even remember there are other factories [in Brazil], let alone other countries in the world" (Interview R5, November 2014). Accordingly, the first steps to build a network are usually taken by international, foreign or national domestic organisations. Table 1 does not exhaust all of the declared motivations to build networks, but it offers a useful summary of the main resources and expectations involved in this process.

Table 1: Profiles of union leaders associated with company-based union networks

\begin{tabular}{|l|l|l|l|}
\hline \multicolumn{1}{|c|}{ Profile } & \multicolumn{1}{|c|}{ Typical examples } \\
$\begin{array}{l}\text { Globally } \\
\text { oriented }\end{array}$ & $\begin{array}{l}\text { IndustriALL leaders; } \\
\text { CUT's International } \\
\text { Relations Secretariat }\end{array}$ & $\begin{array}{l}\text { Resources } \\
\text { agreements; research, training } \\
\text { and education; global mandate } \\
\text { and legitimacy }\end{array}$ & $\begin{array}{l}\text { Global strategies to } \\
\text { confront } \\
\text { transnational capital }\end{array}$ \\
\hline $\begin{array}{l}\text { Company- } \\
\text { oriented }\end{array}$ & $\begin{array}{l}\text { Unionists in TNCs' } \\
\text { countries of origin }\end{array}$ & $\begin{array}{l}\text { Financial resources; access to } \\
\text { global decision-makers in } \\
\text { TNCs }\end{array}$ & $\begin{array}{l}\text { Union alliances in } \\
\text { specific companies }\end{array}$ \\
\hline $\begin{array}{l}\text { Nationally } \\
\text { oriented }\end{array}$ & $\begin{array}{l}\text { Union centrals and } \\
\text { industrial confederations in } \\
\text { Brazil }\end{array}$ & $\begin{array}{l}\text { Direct contact with local } \\
\text { unions; expertise in domestic } \\
\text { labour relations }\end{array}$ & $\begin{array}{l}\text { International } \\
\text { influence and } \\
\text { nationalisation of } \\
\text { union prerogatives }\end{array}$ \\
\hline $\begin{array}{l}\text { Locally } \\
\text { oriented }\end{array}$ & $\begin{array}{l}\text { Local union officials and } \\
\text { workplace representatives }\end{array}$ & $\begin{array}{l}\text { Shop-floor organisation; legal } \\
\text { monopoly on trade union } \\
\text { prerogatives }\end{array}$ & \begin{tabular}{l} 
Local power in TNCs \\
\hline
\end{tabular}
\end{tabular}

\footnotetext{
${ }^{4}$ The studied networks are explicitly supported by CUT and FS. Local unions affiliated to the União Geral dos Trabalhadores (UGT), Central dos Trabalhadores e Trabalhadoras do Brasil (CTB), Conlutas and Intersindical, alongside unaffiliated unions, were also part of at least one network on their own discretion. It is worth noting, however, that there are unions which are critical of company-based initiatives and do not take part in networks.
} 
In brief, there are different priorities at play in the selection of target companies. IndustriALL favours promising global initiatives and foreign unions prioritise TNCs headquartered in their countries. Much like GUFs at the global level, national industrial confederations see in networks the opportunity to affirm new prerogatives in the absence of a formal representation mandate, so emerging Brazilian TNCs or companies widespread throughout the country are typical priorities. Customarily, a few companies are chosen through a compromise between the major actors involved. Once a sufficient number of organisations agree to target certain TNCs, funds are provided and a study is commissioned to analyse the companies' operations and, crucially, to map the relevant local unions organising in different parts of the country. ${ }^{5}$

As we have argued, networks have been able to gain wider national support, which makes direct opposition on political grounds less likely. However, there is no guarantee that local unions affiliated to sympathetic centrals will be receptive. A local leader at a German chemical company explained that attachment to local autonomy is "an instinct that is hard to change. The union is like a town hall; each town has its own" (Interview R6, November 2014). At first, networks may be perceived as an assault on local prerogatives. Furthermore, union presidents may be wary of exposing young workplace representatives to an environment outside of local oversight. Accordingly, an experienced IndustriALL leader warns that networks should not disturb local arrangements:

When the person in the network feels more powerful than the local union president, and starts to push his own politics, that's a mistake. The union will not accept that, because legally in the country the mandate belongs to the union. The network cannot become too independent from the union (Interview R7, August 2014).

All things considered, at the national level company networks are alliances of local unions. The scope of a network depends on the target company. In theory, a network could be formed by representatives in a company with two factories in the country, but they usually involve multiple locations (see Figure 1). National meetings are held regularly, usually once a year. The participation of observers and lecturers from national organisations and IndustriALL is not uncommon. In these meetings, unions exchange information and decide on an action plan that will guide their actions until the next assembly. Usually, plans involve visits to present the initiative to potential new members, solidarity actions and coordinated campaigns. When there are global networks in place, one or a few members are chosen to participate in international activities. Voting is rare and decisions are almost always consensual. In between regular meetings, members of a network establish regular communications using the Internet, instant messaging and other technologies.

\section{Local Roots and the Bread and Butter of Trade Unionism}

The decision to prioritise the mitigation of tensions is not without consequences. Networks refrain from reaching out to workers directly, thus oppositional political minorities are excluded. Furthermore, networks avoid polarising subjects such as different conceptions of trade union practices. Global, foreign and national leaders often complain that networks are locked into the

\footnotetext{
${ }^{5}$ The cooperation between CUT and FNV created the Social Observatory Institute, which specialises in the production of studies on TNCs.
} 
"small world of the local union". Nevertheless, representatives engaged in networks are insistent upon the argument that they do not threaten established unions. According to a trade unionist in a German metal conglomerate, 'We won't do a thing without authorisation from the local union. We respect its autonomy. We're here to offer support” (Interview R8, December 2014).

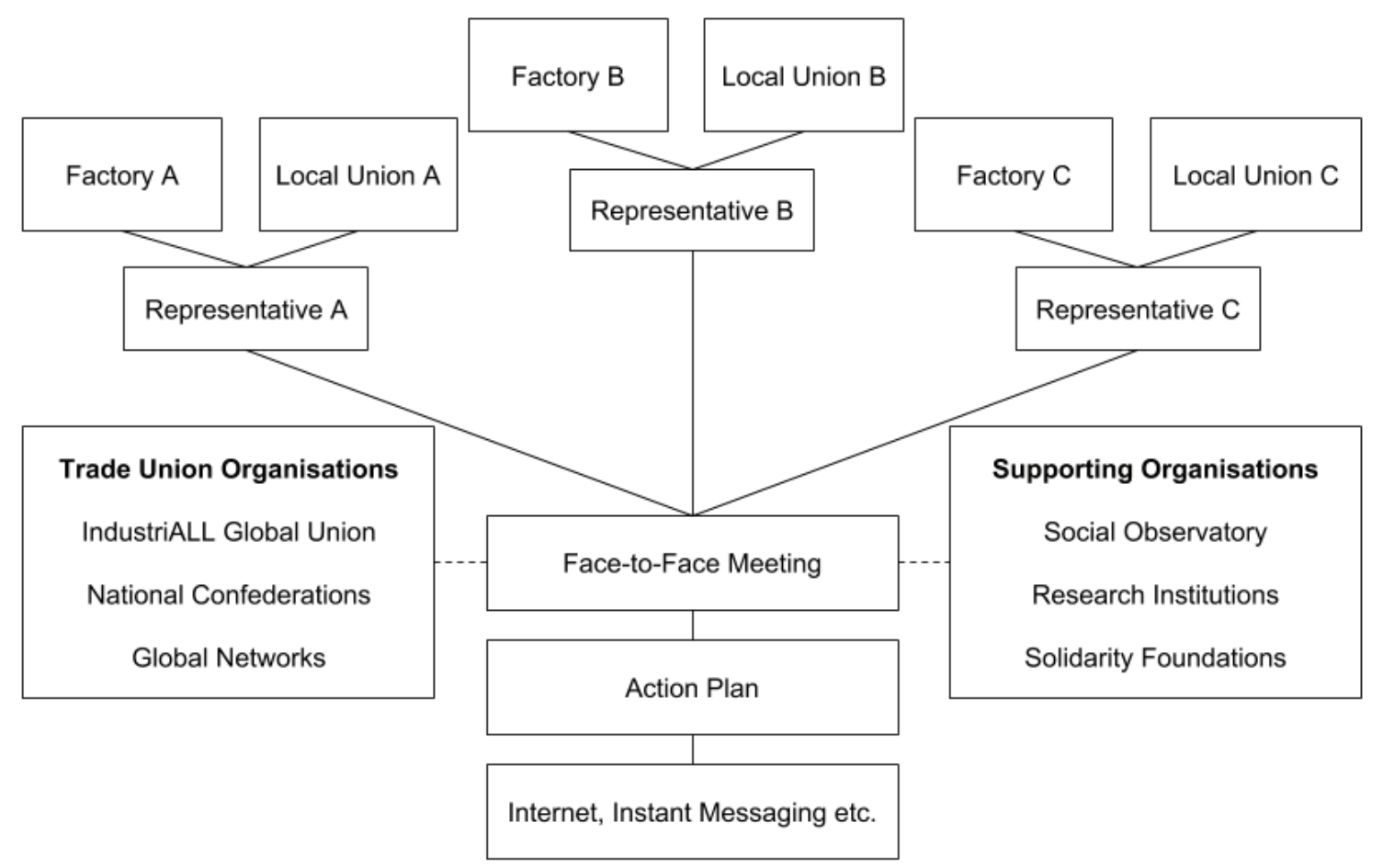

Figure 1: A typical company union network in Brazil

As ill-equipped as they might be to carry out such initiatives on their own, local unions exercise an informal power of veto and, in this way, they are able to shape networks to a considerable extent. In this manner, a method of consensus and compromise is well-suited to creating a shared platform around the issues that most concern local representatives in the factories. "We work with what is possible, what unites us. What divides us, we won't discuss", explains a local unionist in a Dutch chemical corporation (Interview R9, October 2014). Common topics discussed within company networks are wages, benefits, safety, health and working conditions - that is, issues that emanate from local agendas. In the words of a national leader of CUT's metalworkers:

People expect something very intellectual, very bureaucratic. It is not like that! I like to talk about my father, who worked for Ford and Mercedes. In the seventies, workers showed one another their pay checks to know how much they earned. They exchanged information. This is what the strategy of the networks is all about today. Within the same company, first inside the country, to try to make wages and benefits the same for everyone (Interview R8, December 2014).

Indeed, the simple exchange of information has immediate benefits. Provided with information from multiple sites, local representatives previously limited to the reality of a single factory are better equipped to challenge the positions of local bosses. As one unionist explained, 
however, the decisive step forward is to "push a situation" to the company. This means building a united front to fight for a relationship between unions and companies beyond the local level (Interview R8, December 2014). In order for this approach to be effective, however, alliances cannot be restricted to union officials. The traditional practice in the metal and chemical industries in Brazil is for decisions regarding specific companies to be made in open assemblies at the gates of the factories and, in this way, workers must be convinced that a coalition with their faraway colleagues is desirable.

In a typical case, IndustriALL decided to campaign for a global agreement with a French chemical company we will call "Group X". Brazilian representatives were very receptive and, after a first meeting formalised a national network, unions decided to publish a joint version of their usual means of communication - a bulletin to be distributed in the factories. Signed by five different local unions, CUT and IndustriALL, the pamphlet called: "To the struggle, working men and women of Group X! You have another tool to fight for your rights!" The document emphasised the need for workers to be "globally organised" and highlighted contacts established via teleconference with an American representative of the United Steelworkers, plans to build a global network and IndustriALL's campaign for a GFA. At the national level, unions agreed on a platform that included the equalisation of wages and benefits across the factories. Directly engaging workers, the bulletin asked:

Why are there different wages and benefits in different sites of the group? Would it not be fair to equalise the rights at least inside the country? In your workplace, are there the benefits described below? If not, what is the reason?" 6

In this sense, unions appeal to differences among workers performing the same job in different locations to promote solidarity against the "divide and conquer", whipsawing strategy employed by TNCs. According to a leader in another network:

Workers are used to seeing the union gathering people at the gate of the factory. It's easy to position the sound truck and assemble workers for hours. You start to talk about things that are part of their lives; you explain what is happening there [in another factory]. You say that the problems over there can affect employment here. There's no safety, their wages are lower, so their product is cheaper. If we don't have solidarity with each other, this will affect both plants. But one can live with the other, without one being pitched against the other (Interview R8, December 2014).

Naturally, local concerns are not always easy to dismiss. That was the case of a network dealing with the threat of a factory being closed. After multiple attempts to make the site viable, it was decided that the only realistic solution was for a stronger factory to give up part of its production in favour of the struggling location. A workplace representative found himself in a tough spot when proposing the idea to his fellow workers being asked to make the sacrifice:

It was a hard, difficult debate. To come out and say, 'Look, this work you're doing, we have to give it to them so they don't lose their jobs'. Workers looked back at me and said, 'Gee, you're taking away my work, it will be my job on the line in a few days!' (Interview R5, November 2014).

In spite of their fears, a majority of workers voted for the network's proposal and the jobs

\footnotetext{
${ }^{6}$ First bulletin of a trade union network in a French chemical company in Brazil, 2013. The bulletin is available in the local union archives.
} 
were saved. There are similar reports of solidarity in different companies. This is evidence that local priorities are relevant, but not insurmountable. Given enough time to overcome initial doubts and develop mutual trust, unions can combine their local roots to promote concerted strategies. Moreover, solidarity based on principles of justice and equality and the conviction that workers should stand united when dealing with bosses are a central part of the strategy. In this sense, the studied cases suggest that company alliances may in fact be used to connect global policies to local struggles.

\section{Transnational Connections and European Aspirations}

Domestic networks are invariably connected to IndustriALL, but the description presented so far is largely based on the experiences of local unions organising within Brazil. In practice, the degrees to which the activities of particular networks are transnationalised vary considerably. Whenever funding is available, local unions are glad to take part in international activities and, in this sense, the official position is that national alliances are steps towards the realisation of global networks. However, as noted by Croucher and Cotton (2009: 76), "staggeringly, given their strategic importance and the substantial GUF resources dedicated to them, there are no examples of truly global company networks". Overall, international activities tend to be few and far between. Their existence depends on the funds available to GUFs or provided by unions in companies' home countries, which means that foreign priorities beyond the grasp of local unions are often determinant. Nevertheless, more informal international contacts can be important to support local networks.

From the perspective of local representatives, the most valued foreign allies are precisely the unions in direct contact with companies' headquarters. Taking advantage of these connections, local representatives can outflank factory bosses and challenge the despotism that results from the insularity of local authority. A local unionist argued that after these connections were in place, bosses realised that union officials could "deal with it upstairs", so their demands started to be taken seriously (Interview R10, October 2014). Although in theory this dynamic could be replicated in any TNC as long as the relevant unions are involved, in practice positive outcomes are more likely in cases where home-country unions are able to influence global executives, notably in companies which have a tradition of dialogue with union representatives.

The prevalence of European approaches to global union strategies in the manufacturing industries reinforces these features, as social dialogue and partnership arrangements support many such initiatives. This is noticeable in the composition of Global Framework Agreements. IndustriALL has signed forty-five GFAs but only four with companies headquartered outside of the European Union. In view of that, Fichter and McCallum (2015: 81) argue that in order to have "any real meaning", GFAs "must be relevant to all potential and existing actors, global and local" and that "it is imperative that actors beyond those in the limited social partnership setting are involved". The question, then, is whether the method favoured by influential foreign unions is appealing in Brazil.

In view of our cases, at first glance the answer would be affirmative. Cooperation with European unions is influential regardless of target companies' countries of origin. The few instances where representatives from Brazil were included in transnational co-partnership arrangements in German companies are well-regarded and contacts with European Works Councils (EWCs) set farfetched but highly prized goals. Furthermore, these dispositions were part of broader changes in union practices in the country from the 1990s, when CUT "increasingly aligned itself with union experiments based on European social democratic 
unionism" (Antunes and Santana, 2014: 17).

The relevance of such affinities notwithstanding, one should not take the argument too far. Given that interactions between unionists and managers at the local level in Brazil tend to be hostile, advances in social dialogue practices were always the result of determined struggles, the outcomes of which never quite match the stability perceived in European practices and legislation. Overall, the use local unions make of social dialogue discourses is pragmatic rather than ideological. Although speaking the language of foreign commitments and corporate social responsibility favoured by companies may be useful, local unions do not abandon their traditional methods and conflict remains part of the equation:

I always tell my people that there's a proverb that says that peace is made from strength. We can have all this talk about social dialogue, Global Framework Agreements, but if workers are not strong in the rank-and-file, after the first crisis it's all gone. ... Networks are able to promote this idea of social dialogue, which companies like. We have to take advantage of that and use their contradictions against them. So we talk, but without ever giving up our greatest tools: speaking to workers and the strike (Interview R8, December 2014).

Accordingly, the history of company networks in Brazil is marked by episodes of disruption and local unions are seldom naïve about the possibility of a direct incorporation of foreign arrangements. A local official in a German chemical company warned that "social dialogue is good, but also dangerous". He argued that "one should not lose sight of [the contradictions in] the relationship between capital and labour; otherwise you fall into a trap and sometimes there's no way out" (Interview R11, September 2014).

The caution with imported practices is best illustrated by local attitudes regarding Global Framework Agreements. Leaders in Brazil often argue that such agreements contain provisions that are too abstract to be used effectively, and criticise them for being disconnected from local struggles. A recurring joke among local unionists is that GFAs are not the result of workers' struggles, but rather casually signed when a foreign union president happens to have dinner with the Chief Executive Officer of a global corporation in Europe. Others demand greater participation in the negotiation of future agreements. These positions notwithstanding, the prevailing feeling among local representatives is more about indifference than outright opposition or engagement. GFAs are reduced to one more tool in a wider set of principles and documents that can be used to legitimise workers' demands within TNCs, such as codes of conduct and international conventions.

In effect, local unions prefer to voice their concerns directly. Regarding cross-border negotiations with TNCs, a typical strategy has been the pursuit of "social dialogue rounds" as institutionalised bargaining spaces between unions and managers at the national level. Unlike the processes that produce GFAs, these are held periodically, involve local representatives directly and deal with concrete issues. In a few cases, Brazilian networks have taken the initiative to reach out to unions in neighbouring countries to create networks at the regional level, which resulted in the expansion of such bargaining spaces.

In one of these instances, almost twenty Brazilian and Argentinian unionists sat with corporate executives of a Dutch chemical company in 2013. In their speeches, workers' representatives mobilised United Nations and International Labour Organization conventions, the legitimacy of IndustriALL and the support of Dutch unions to demand a "social dialogue in the workplace", by which they meant the presence union representatives in the factories. Corporate executives were reticent about providing a definitive answer and emphasised the unenforceable nature of the dialogue. Unions were not satisfied and established a deadline, 
announcing that "if a response is not possible, the Network will seek other measures to ensure that its demands are met"7. In this manner, local unions use outside opportunities selectively, favouring strategies which can more readily be connected to their established practices.

In sum, networks allow unions to combine local power with foreign support to fight for the material improvement of the conditions of workers in the company and, when they are sufficiently strong, for greater union influence across different scales. The most common tangible achievements are the equalisation of working conditions and parts of the remuneration between factories, particularly complements to wages such as profit-sharing and benefits, and the strengthening of union representatives in different scopes, from the recognition of workplace representatives to national and international spaces of influence and negotiation.

\section{Limited Resources and the Path of Least Resistance}

Although networks translate foreign ideas into local terms, it should be noted that most positive cases exist under conditions that are not easily replicated. In this way, networks are limited to relatively few companies. Our last survey, conducted in 2019, identified twenty-four active networks operating in the metal and chemical industries in Brazil. Their target companies are headquartered in Germany (8), Brazil (6), non-German Europe (5), the United States (4) and Asia (1). Compared to GFAs, networks in Brazil are more diverse, but European and German TNCs are still over-represented. This is a consequence of foreign national priorities, but also of the fact that, being under-resourced, promoters of networks prefer to prioritise companies in which they perceive a greater chance of success. The hope is that positive cases will encourage local unions to take on the challenge of building networks on their own.

There is evidence that this approach has been at least partially effective. Well-known cases of success are often mentioned as inspiration by local representatives working in different settings. However, there is the risk that social dialogue will be assumed to be the goal to be pursued regardless of other considerations. The outcome of the efforts mentioned in a previous section to create a network in "Group X" indicates that stern opposition from managers can trap young networks in a stalemate. In this case, relations between the company and local unions were very hostile, and included the use of police to suppress strikes. According to a local official, unions were "very enthusiastic" about the network, but after bosses ignored their attempt at a dialogue they were left with a feeling of frustration. In his words, "We gave the company a chance, but it's no use. Here, things only change with a strike. There's no other way" (Interview R12, October 2014). Could the network, however, be useful if it worked alongside the usual tactics?

Of course, if the network was functioning.... If we could strike here and in other factories at the same time. If we stop and they keep working, it's no good. The production can be transferred, that's no problem. They can do it in Mexico, in Chile. If we were organised at least here in Latin America, in the United States... Yes, then it would be good. The dream is good. Nobody takes the dream away from us. The dream is great (Interview R12, October 2014).

The problem, then, is not that networks can only be conceived within the confines of social dialogue, but that following a different path is difficult. Funded by organisations invested in national priorities or seeking the path of least resistance, networks facing hostile settings may be abandoned before they have a chance to mature. This is a limitation that cannot be overcome

${ }^{7}$ Report on the "Regional Social Dialogue" in a Dutch chemical corporation. Source: local union archives. 
without a decision to dedicate greater resources to such initiatives. From the perspective of local unions, this is seldom realistic. Responsible for organising in several different companies in their territories, investing too much in organising a single corporation is often out of the question. As a workplace representative in a German chemical company reflected, "there are two hundred companies under our union; how can we spend so much money on a single one?" (Interview R13, October 2014).

The official solution has been to pursue corporate funding, which creates additional problems. In one instance, local representatives in a German car parts maker admitted to omitting offering this arrangement to workers, arguing that while in Germany this kind of relationship is accepted, "in Brazil we're not at this point" (Interview R14, October 2014). Another local leader, whose network was not yet funded by the company, stated he "didn't want to think about it" and joked that, for the time being, he could "still sleep in peace" (Interview R15, November 2014). Yet another unionist argued that he felt "completely trapped in the financial relationship with the company" and maintained that "independence would grant a much greater benefit" (Interview R8, December 2014). Although our research did not find evidence of direct corporate co-optation of networks, there is no doubt that companies use this situation to their advantage, limiting the scope of what can be negotiated and refusing to fund activities that include unwanted third parties.

\section{Persisting Structures and Restricted Membership}

A patent shortcoming of the studied networks is that although they connect unions across borders, they do not expand their member base (see Figure 2). These are alliances of unions of metal and chemical workers and, consequently, their strategies are based on the experiences of their members: traditional manufacturing workers, mostly males directly employed in production. In this sense, the very idea of network organisation can be misleading. While this concept is often associated with a democratic approach opposed to old bureaucratic hierarchies, in this case the idea is used to introduce networks as a novelty that will not disturb established structures. According to a specialist, "this theoretical shift is important: the change from a global federation or committee to a network. Those are rigid structures that represent power, and that could be a threat to the already existing power of local unions" (Interview R4, August 2014). To put it simply, networks amend rather than overcome the established union structures and, in this way, they incorporate many of its limitations.

For instance, a local unionist in a German chemical company acknowledged that it would be beneficial to include white-collar workers, who are severely underrepresented in networks. He argued that they could provide "very important information about profits, investments, where the technology is going". However, he claimed that consistent cooperation is difficult because "there's still a lot of prejudice between administrative workers and shop-floor, blue-collar workers" (Interview R6, November 2014). In a wider sense, including new leaders would create tensions and disrupt customary practices. As long as unions do not bridge the gap between these workers at the local level, networks will inherit these divisions.

Likewise, networks fail to organise contract and outsourced workers. This is important because directly employed workers may be subjected to conditions of exploitation and injustice, but, as a metalworker unionist from São Bernardo defined, "the barbarism is in the production chain" (Interview R2, July 2014). Stronger union presence on the shop floor often results in solidarity with contract workers, who in this sense indirectly benefit from networks; however, the efficacy of this kind of informal support is severely limited by restrictions imposed by national 
labour legislation. Moreover, institutionalising informal representation of contract workers at the company level is difficult because TNCs refuse to recognise them as part of social dialogue arrangements.

Furthermore, activists protesting the negative impacts of TNCs on communities and the environment are not represented. According to a former unionist who worked on the early CUTMulti project, the possibility for the participation of these groups was well-received when networks were initially proposed. After what he considered a "very sad meeting", however, the idea was shut down because some of the involved unions foresaw conflicts between their agenda and the defending of jobs and production (Interview R16, August 2014). Again, the sort of dialogue networks prioritise is ill-suited to dealing with an expansive agenda. Although unions often pursue such alliances on their own, the researched alliances were soon defined as strict trade union networks.

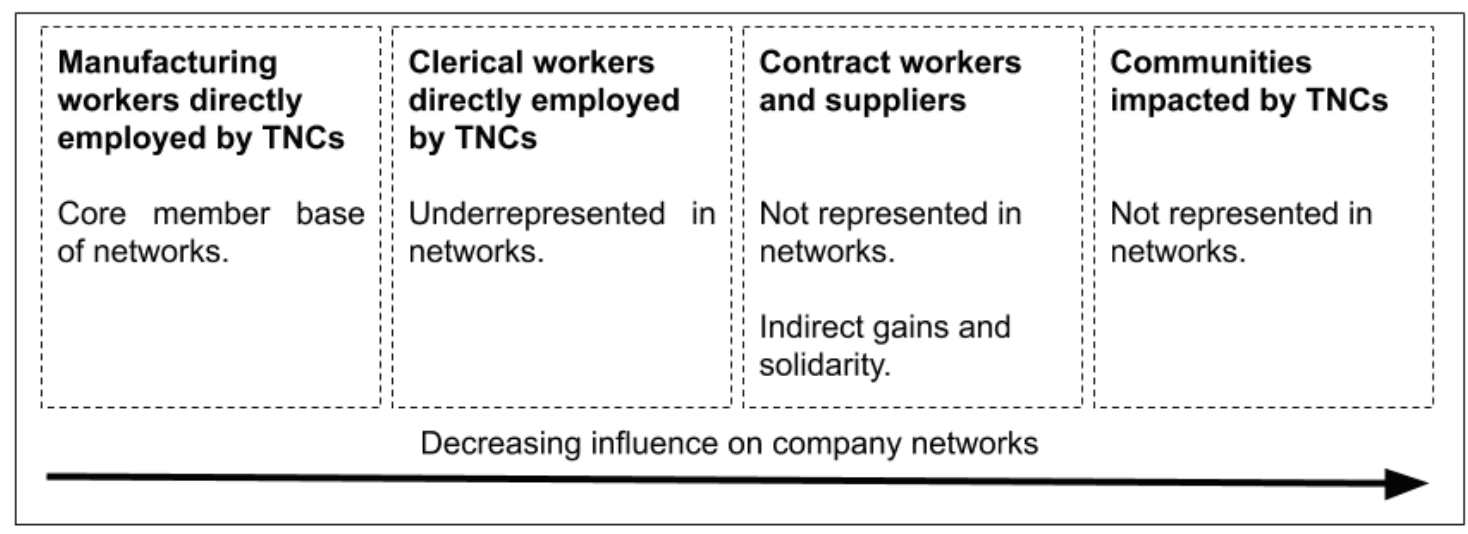

Figure 2: Varying influence on company networks

\section{Concluding Remarks}

In the introduction, we contrasted theoretical insights on new forms of labour transnationalism and the sobering conclusions of studies which emphasise the persistence of national concerns, power imbalances and traditional structures. Our findings reflect these conflicting trends. On the one hand, company networks combine local power and global opportunities, making internationalism relevant to workers in the factories. On the other, they exclude relevant parts of the workforce and do not always succeed in different settings. The crux of the matter is that these limitations are not the result of a single factor. As we have argued, divisions may be reinforced by corporate influence and foreign priorities, but they are also deeply entrenched in local structures. In effect, the studied cases are supported by a precarious compromise made possible by the partial alignment of different sets of interests: the willingness of certain companies to establish a dialogue with a segment of the workforce, the concerns of foreign unions and domestic organisations at the national level and, last but not least, the priorities of local unions operating within the limits of restrictive legislation. In this sense, networks are shaped by material, political and structural constraints that are intertwined and manifested in uneven relations established between workers and TNCs, between different union organisations, and between unions and the state.

However, although the existing situation favours the prevalence of certain practices, it does

Global Labour Journal, 2019, 10(3), Page 204 
not suppress underlying tensions and contested relations. Accordingly, the current status is maintained only as far as alternatives are blocked by contingent compromises. Our main argument, in this sense, is that company networks in Brazil were not a passive outcome of foreign ideas and external priorities. We have emphasised the role of local unions, but one should not overlook that broader domestic concerns were also crucial. The studied cases would not have been possible without CUT's determination to play an internationally active role and, at the national level, in the absence of its perceptions on the flaws of union localism. Therefore, the imbalances between domestic and foreign unions and the limitations of local unionism are constraints, but they were also issues targeted by the incorporation of global union strategies in Brazil.

Many of the hopes inspired by these endeavours seem to have been dashed on the rocks of the political and economic turmoil that has swept the country in the last few years. Support for the Workers' Party was split in 2014 and union rivalries were rekindled during the fall of Dilma Rousseff's government in 2016. Affiliations to IndustriALL have not been impacted so far and networks are relatively shielded from political disturbances, but the ensuing strife reverberated in other international bodies. ${ }^{8}$ On the other hand, opposition to anti-labour policies and attacks on unions by subsequent presidents suggest the possibility of renewed alliances. Overall, international solidarity of a more political character is expected to assume greater importance, but the future of labour internationalism in Brazil is largely uncertain.

In regard to networks in particular, the most relevant developments have been the end of the "union tax" in 2017 and additional restrictions placed on optional contributions in 2019. The immediate consequence was the financial debilitation of union organisations. The other side of the coin is that the foundations which traditionally supported the resilience of local unionism have been fractured. As a result, even the hermetic space of company networks is being tested. In early 2019, during the most recent meeting of a network we have observed, the intrusion of ideas such as the formation of national unions was inevitable.

In 2014, a Brazilian global unionist argued that a "political understanding that the global is important" should be connected to an "openness to work in paralegal arrangements" - that is, a willingness to challenge established practices. He lamented, however, that unionists in Brazil were still "trapped in the legal structure" (Interview R7, August 2014). These matters will not be decided within the confines of company networks, but the need to reinvent the local union movement may now lend credibility to alternatives which a few years ago would have been considered unrealistic. In this sense, it is not insignificant that different dispositions endure behind the current shortcomings. This is better illustrated by the statement of a local unionist which, expressing aspirations rather than the effective state of his network, offered another perspective on our subject:

The network has a greater role than debating the day-to-day, if the food is good, if wage increases were good. The network should talk about sustainable development, the question of the environment, the relationship between capital and labour in a wider sense to preserve workers' rights and human dignity. This macro discussion, when you unite a lot of people around it, you get much stronger. That was the idea when we created the network. We still have a long way ahead of us (Interview R10, October 2014).

\footnotetext{
${ }^{8}$ Força Sindical left TUCA and formed the Alternativa Democratica Sindical as a rival Latin American international federation in 2017.
} 


\section{REFERENCES}

Abreu, A.R. de P., H. Beynon and J.R. Ramalho (2000) “The Dream Factory”: VW's Modular Production System in Resende, Brazil. Work, Employment and Society, 14(2): 265-282. https://journals.sagepub .com/doi/10.1177/09500170022118400.

Anner, M. (2003) Industrial Structure, the State, and Ideology: Shaping Labor Transnationalism in the Brazilian Auto Industry. Social Science History, 27(4): 603-634. https://doi.org/10.1017/ $\underline{\text { S0260210500005337. }}$

Anner, M., I. Greer, M. Hauptmeier, N. Lillie and N. Winchester (2006) The Industrial Determinants of Transnational Solidarity: Global Interunion Politics in Three Sectors. European Journal of Industrial Relations, 12(1): 7-27. https://journals.sagepub.com/doi/10.1177/0959680106061368.

Antunes, R. and M.A. Santana (2014) The Dilemmas of the New Unionism in Brazil: Breaks and Continuities. Latin American Perspectives, 41(5): 10-21. https://journals.sagepub.com/doi/abs/10.1177/ $\underline{0094582 X 14541228 .}$.

Bourque, R. and M-A. Hennebert (2011) The Transformation of International Trade Unionism in the Era of Globalization. Just Labour: A Canadian Journal of Work and Society, 17 \& 18: 1-17. https://doi.org/ $\underline{10.25071 / 1705-1436.28 .}$.

Campos, A.G. (2016) Sindicatos no Brasil: O que esperar no futuro próximo? Texto para Discussão, Instituto de Pesquisa Econômica Aplicada. 2262: 7-29. http://repositorio.ipea.gov.br/handle/11058/7353 (date accessed 3 July 2018).

Central Única dos Trabalhadores (CUT) (2003) Relatórios dos Seminários do projeto CUT-Multi. Unpublished report on the CUT-Multi Project, available in CUT archives.

Central Única dos Trabalhadores (CUT) (2006) Caderno de Resoluções do $9^{\circ}$ Congresso. https://admins.cut.org.br/system/uploads/document/89c082842a387138814fd152d5f00c73/file/9congresso-nacional-da-cut-9-concut-05-a-09-06-2006.pdf (date accessed 20 September 2019).

Costa, H.A. (2009) The Place of the International Relations Policy within National Trade Union Organisations: The Case of CUT in Brazil. Lusotopie, 16(2): 41-64. https://doi.org/10.1163/ 17683084-01602005.

Cotton, E. and R. Gumbrell-McCormick (2012) Global Unions as Imperfect Multilateral Organizations: An International Relations Perspective. Economic and Industrial Democracy, 33(4): 707-728. https://journals.sagepub.com/doi/full/10.1177/0143831X12436616.

Croucher, R. and E. Cotton (2009) Global Unions, Global Business. Global Union Federations and International Business. London: Middlesex University Press.

Evans, P. (2010) Is it Labor's Turn to Globalize? Twenty-first Century Opportunities and Strategic Responses. Global Labour Journal, 1(3): 352-379. https://doi.org/10.15173/glj.v1i3.1082.

Fairbrother, P. and N. Hammer (2005) Global Unions: Past Efforts and Future Prospects. Industrial Relations, 60(3): 405-431. https://doi.org/10.7202/012153ar.

Fichter, M. and J.K. McCallum (2015) Implementing Global Framework Agreements: The Limits of Social Partnership. Global Networks, 15(S1): 65-85.

Ford, M. and M. Gillan (2015) The Global Union Federations in International Industrial Relations: A Critical Review. Journal of Industrial Relations, 57(3): 456-475. http://journals.sagepub.com/doi/abs/ $10.1177 / 0022185615574271$.

Garver, P., K. Buketov, H. Chong and B.S. Martinez (2007) Global Labor Organizing in Theory and Practice. Labor Studies Journal, 32(3): 237-256. https://journals.sagepub.com/doi/10.1177/ 0160449X07299712.

Hyman, R. (2005) Shifting Dynamics in International Trade Unionism: Agitation, Organisation, Bureaucracy, Diplomacy. Labor History, 46(2): 137-154. https://www.tandfonline.com/doi/abs/ $\underline{10.1080 / 00236560500080758 .}$. 
Lang, K. and M. Gagnon (2009) Brazilian Trade Unions: (In)Voluntary Confinement of the Corporatist Past. Relations Industrielles/Industrial Relations, 64(2): 250-269. https://doi.org/10.7202/037920ar.

McCallum, J.K. (2013) Global Unions, Local Power: The New Spirit of Transnational Labour Organizing. Ithaca, NY: Cornell University Press.

O'Brien, R. (2000) Workers and World Order: The Tentative Transformation of the International Union Movement. Review of International Studies, 26(4): 533-555. https://doi.org/10.1017/ $\underline{\text { S0260210500005337. }}$.

Oliveira, F. (2006) Who is Singing L'International Again? A Brazilian Illustration. In Another Production is Possible: Beyond the Capitalist Canon, edited by B.S.S. Santos. New York: Verso.

Webster, E., R. Lambert and A. Bezuidenhout (2008) Grounding Globalization: Labour in the Age of Insecurity. Oxford: Blackwell.

Wills, J. (1998) Taking on the CosmoCorps? Experiments in Transnational Labor Organization. Economic Geography, 74(2): 111-130. https://www.tandfonline.com/doi/abs/10.1111/j.1944-8287.1998.tb 00108.x.

\section{Quoted Interviews}

R1 - Workplace representative, German metal conglomerate A, interviewed September 2018.

R2 - Metalworker unionist and former workplace representative in German automobile manufacturer B, São Bernardo do Campo, interviewed July 2014.

R3 - FS leader, interviewed August 2014.

R4 - Staff member, CUT-Multi project, interviewed August 2014.

R5 - Workplace representative in German automobile manufacturer B, interviewed November 2014.

R6 - Local unionist, German chemical company C, interviewed November 2014.

R7 - Brazilian IndustriALL leader, interviewed August 2014.

R8 - Local unionist, German metal conglomerate A, interviewed December 2014.

R9 - Local unionist, Dutch chemical corporation D, interviewed October 2014.

R10 - Local unionist, Belgian chemical corporation E, interviewed October 2014.

R11 - Local unionist, German chemical company F, interviewed September 2014.

R12 - Local unionist, French glass manufacturer Group X, interviewed October 2014.

R13 - Workplace representative, German chemical company G, interviewed October 2014.

R14 - Workplace representative, German car parts maker H, interviewed October 2014.

R15 - Local unionist, American glass manufacturer I, interviewed November 2014.

R16 - Former unionist in the CUT-Multi project, interviewed August 2014.

\section{ACKNOWLEDGEMENT}

This study was funded in part by the Coordenação de Aperfeiçoamento de Pessoal de Nível Superior (CAPES), the National Council for Scientific and Technological Development (CNPq) and the São Paulo Research Foundation (FAPESP). 


\section{BIOGRAPHICAL NOTES}

Ricardo Framil FILHO is a PhD student in Sociology at the University of São Paulo. His research revolves around social movements, labour and globalisation. [Email: framilfilho@gmail.com]

Leonardo Mello e Silva is a Researcher at the Department of Sociology, University of São Paulo, Brazil, and teaches Sociology of Work and Development in the same institution. [Email: leogmsilva@hotmail.com] 